\title{
Analisa Pengaruh Kualitas Website PPDB Terhadap Kepuasan Pengguna
}

\author{
Lilyani Asri Utami, M.Kom \\ Program Studi Sistem Informasi \\ STMIK Nusa Mandiri Jakarta \\ Jl. Damai No.8 Warung Jati Barat, Margasatwa- \\ Jakarta Selatan \\ lilyani.lau@nusamandiri.ac.id
}

\author{
Ahmad Ishaq, M.Kom \\ Program Studi Manajemen Informatika \\ AMIK BSI Purwokerto \\ Jl. HR. Bunyamin 106, Purwokerto Utara, \\ Kabupaten Banyumas, Jawa Tengah \\ ishaq@bsi.ac.id
}

\author{
Nurul Maulidiyah \\ Program Studi Sistem Informasi \\ STMIK Nusa Mandiri Jakarta \\ J1. Damai No.8 Warung Jati Barat, Margasatwa-Jakarta Selatan \\ nuruldhyah@gmail.com
}

\begin{abstract}
Abstrak - Website Penerimaan Peserta Didik Baru (PPDB) memberikan kemudahan bagi orang tua dan calon peserta didik baru dalam mengetahui informasi mengenai pelaksanaan seleksi penerimaan peserta didik baru, melakukan pendaftaran serta melakukan pemantauan hasil seleksi karena dapat dengan mudah diakses melalui gadget atau perangkat lain yang terkoneksi dengan internet. Permasalahan yang diangkat dalam penelitian ini adalah apakah kualitas dari website PPDB berpengaruh terhadap kepuasan pengguna pada SMKN 57 Jakarta. Penelitian ini berfokus pada kepuasan pengguna website PPDB menggunakan metode webqual yang terdiri dari 3 variabel yaitu kualitas kegunaan (usability), kualitas informasi (information quality), dan kualitas interaksi (interaction quality). Data yang digunakan dalah data primer, yaitu dengan menyebar kuesioner menggunakan skala likert dengan 20 pernyataan kepada 95 responden. Data yang diperoleh dan diolah menggunakan teknik analisis regresi linier berganda dengan menggunakan software SPSS 16. Berdasarkan variabel webqual, hasil analisis menyatakan kualitas kegunaan tidak berpengaruh terhadap kepuasan pengguna, sedangkan kualitas informasi dan kualitas interaksi berpengaruh terhadap kepuasan pengguna.
\end{abstract}

Kata Kunci: Website Penerimaan Peserta Didik Baru (PPDB), Webqual, SPSS, Kualitas Website, Kepuasan Pengguna

\section{PENDAHULUAN}

Website PPDB digunakan sebagai sistem informasi yang dirancang oleh Kementrian Pendidikan dan Kebudayaan untuk melakukan seleksi penerimaan peserta didik baru untuk sekolah negeri di berbagai provinsi di Indonesia termasuk provinsi DKI Jakarta. SMKN 57 Jakarta adalah salah satu sekolah negeri di provinsi DKI Jakarta yang menggunakan website PPDB sebagai media pendaftaran peserta didik baru.

Aplikasi PPDB online ini digunakan dan dimanfaatkan oleh calon peserta didik, pihak sekolah dan dinas pendidikan sebagai acuan dalam kapasitas dan jumlah calon peserta didik baru. PPDB berbasis web dijadikan sebagai basis pelayanan dan terus ditingkatkan, sehingga diharapkan dapat memberikan kemudahan bagi siswa dan orang tua hingga masyarakat dalam melakukan pendaftaran [1]

Sistem PPDB Online ini dirancang sedemikian rupa dengan tujuan memberikan kemudahan bagi calon siswa yang mendaftarkan diri serta memberikan jaminan proses yang adil, transparansi, dan akuntabel bagi masyarakat luas [2]. Dengan penggunaan website PPDB memberikan kemudahan bagi orang tua dan calon peserta didik baru dalam mengetahui informasi mengenai pelaksanaan seleksi penerimaan peserta didik baru, melakukan pendaftaran serta melakukan pemantauan hasil seleksi karena dapat dengan mudah diakses melalui gadget atau perangkat lain yang terkoneksi dengan internet.

Penerimaan siswa baru (PSB) Online merupakan produk layanan aplikasi perangkat lunak 
yang online real time dan $100 \%$ berbasis website. Pengefektifan PSB Online tidaklah cukup jika tidak bebarengan dengan kinerja website PSB yang baik. Pengukuran kepuasan user merupakan elemen penting dalam menyediakan pelayanan yang lebih baik, lebih efisien dan lebih efektif [3].

Kualitas sebuah website dapat mempengaruhi kepuasan pengguna dalam menggunakan website tersebut. Metode webqual adalah metode yang tepat dalam mengukur kualitas sebuah website. Dalam metode webqual variabel yang dibutuhkan dalam mengukur kualitas sebuah website antara lain kualitas kegunaan (usability), kualitas informasi (information quality), dan kualitas interaksi (interaction quality) dalam sebuah website.

Berdasarkan uraian dari latar belakang masalah tersebut, maka permasalahannya antara lain:

1. Bagaimana pengaruh kualitas website dalam kegunaanya sebagai website penerimaan siswa baru menurut para pengguna ?

2. Bagaimana pengaruh kualitas website dalam memberikan informasi kepada para pengguna mengenai proses penerimaan siswa baru?

3. Bagaimana pengaruh kualitas website dalam berinteraksi terhadap para pengguna?

\section{LANDASAN TEORI}

\subsection{Tinjauan Pustaka}

A. Sistem Informasi

Sistem adalah kumpulan dari elemen-elemen yang berinteraksi untuk mencapai suatu tujuan tertentu [4].

Informasi adalah data yang diolah menjadi bentuk yang lebih berguna dan lebih berarti bagi penerimanya. Sumber informasi adalah data [4].

Sistem informasi adalah sistem fisik dan sosial yang ditata sedemikian rupa untuk mencapai tujuan tertentu". Berdasarkan pendapat beberapa ahli diatas, maka dapat disimpulkan sistem informasi adalah suatu sistem di dalam organisasi yang mendukung operasional untuk mencapai suatu tujuan tertentu [5].

\section{B. Penerimaan Peserta Didik Baru (PPDB) Online}

SIAP PPDB Online, adalah sebuah sistem yang dirancang untuk melakukan otomasi seleksi penerimaan siswa baru (PSB), mulai dari proses pendaftaran, proses seleksi hingga pengumuman hasil seleksi, yang dilakukan secara online dan berbasis waktu nyata (realtime), yang bertujuan secara umum adalah untuk meningkatkan mutu layanan pendidikan, menciptakan sistem penerimaan siswa baru yang terintegrasi, akurat dan transparan, melaksanakan penerimaan siswa baru dengan lebih praktis dan efisien, menyediakan basis data sekolah yang akurat, memberi fasilitas akses informasi bagi masyarakat dengan cepat, mudah dan akurat [6].

\section{Webqual}

WebQual merupakan salah satu metode atau teknik suatu pengukuran tingkat kualitas website berdasarkan persepsi pengguna akhir. Metode ini merupakan pengembangan dari Servqual yang banyak digunakan sebelumnya pada pengukuran kualitas jasa [7]. WebQual merupakan salah satu metode pengukuran kualitas website yang dikembangkan oleh Stuart Barnes dan Richard Vidgen (1998) berdasarkan persepsi pengguna akhir (end-user) [8].

\subsection{Penelitian Terkait}

Penelitian mengenai sistem informasi PPDB yang dilakukan pada SMK Kota Sukabumi dengan mengadopsi model kesuksesan sistem informasi DeLone and McLean dengan menguji empat variabel yaitu kualitas informasi, kualitas sistem, kualitas pelayanan dan kepuasan pengguna. Hasil penelitian didapat bahwa tidak terdapat pengaruh yang signifikan dari kualitas informasi, kualitas sistem, dan kualitas pelayanan terhadap kepuasaan pengguna [9].

Penelitian pada bidang perbankan yaitu untuk mengetahui kualitas layanan bjb net menggunakan metode Webqual. Secara simultan kualitas layanan bjb net berpengaruh terhadap kepuasan nasabah (Customer Satisfaction). Secara parsial ketiga dimensi WebQual yaitu kegunaan (Ussability), kualitas informasi (Information Quality) dan kualitas interaksi (Interaction Quality) mempengaruhi kepuasan nasabah secara signifikan [10].

Penerimaan peserta didik baru merupakan kegiatan suatu instansi pendidikan yaitu sekolah dimana melakukan penerimaan peserta didik baru guna menyaring calon peserta didik baru yang akan mendaftarkan ke sekolah yang dituju. Permasalahan yang diangkat dalam penelitian ini adalah apakah penggunaan sistem informasi penerimaan peserta didik baru (PPDB) online di Sekolah Menengah Kejuruan (SMK) Kota Sukabumi berpengaruh terhadap kepuasan pengguna. Penelitian dilakukan dengan mengadopsi model kesuksesan sistem informasi DeLone and McLean dengan menguji empat variabel yaitu kualitas informasi, kualitas sistem, kualitas pelayanan dan kepuasan pengguna. Hasil penelitian didapat bahwa tidak terdapat pengaruh yang signifikan dari kualitas informasi, kualitas sistem, dan kualitas pelayanan terhadap kepuasaan pengguna [9]. 


\subsection{Hipotesis}

1). $\mathrm{H}_{1}$ : Terdapat hubungan yang positif antara kualitas kegunaan dengan tingkat kepuasan pengguna website PPDB.

$\mathrm{H}_{0}$ : Terdapat hubungan yang negatif antara kualitas kegunaan dengan tingkat kepuasan pengguna website PPDB.

2). $\mathrm{H}_{2}$ : Terdapat hubungan yang positif antara kualitas informasi dengan tingkat kepuasan pengguna website PPDB.

$\mathrm{H}_{0}$ : Terdapat hubungan yang negatif antara antara kualitas informasi dengan tingkat kepuasan pengguna website PPDB.

3) $\mathrm{H}_{3}$ : Terdapat hubungan yang positif antara kualitas interaksi dengan tingkat kepuasan pengguna website PPDB.

$\mathrm{H}_{0}$ : Terdapat hubungan yang negatif antara antara kualitas interaksi dengan tingkat kepuasan pengguna website PPDB.

\section{PEMBAHASAN}

A. Tahapan Penelitian

Tahapan penelitian yang dilakukan ini yaitu peneliti membuat tahapan/proses dilakukannya penelitian. Dalam penelitian ini terdapat proses atau tahapan penelitian sebagai berikut:

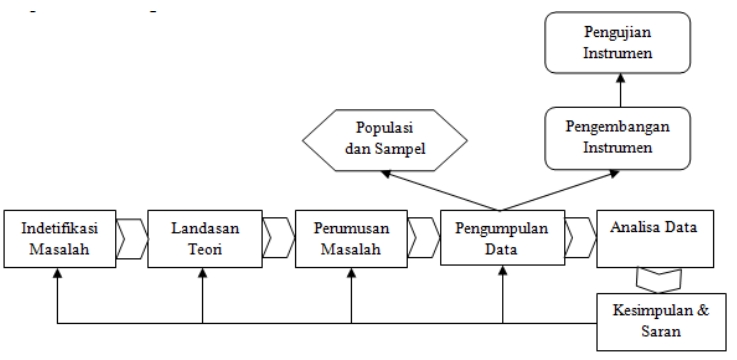

Gambar 1. Tahapan Penelitian

B. Instrumen Penelitian

Pada penelitian ini instrumen digunakan untuk mengukur nilai variabel yang akan diteliti menggunakan kuesioner. Adapun variabel yang digunakan adalah variabel kualitas (X) yaitu kualitas kegunaan (usability), kualitas informasi (information quality), dan kualitas interaksi (interaction quality) website PPDB dan variabel kepuasan pengguna (Y) pada siswa/siswi kelas $\mathrm{X}$ jurusan akomodasi perhotelan SMKN 57 Jakarta.
Tabel 1

Kisi-Kisi Penelitian Analisis Pengaruh Kualitas Website PPDB Terhadap Kepuasan Pengguna pada SMKN 57 Jakarta Menggunakan Metode Webqual

\begin{tabular}{|c|c|c|}
\hline Variabel & $\begin{array}{c}\text { Indikator } \\
\end{array}$ & No Instrumen \\
\hline \multirow[t]{5}{*}{$\begin{array}{r}\text { Kualitas } \\
\text { Kegunaan }\end{array}$} & $\begin{array}{l}\text { a. Adanya penambahan pengetahuan } \\
\text { dari informasi website }\end{array}$ & ( \\
\hline & $\begin{array}{l}\text { b. Interaksi dengan website jelas dan } \\
\text { mudah }\end{array}$ & 2 \\
\hline & $\begin{array}{l}\text { c. Kemudahan menemukan alamat } \\
\text { website }\end{array}$ & 3 \\
\hline & d. Kemudahan untuk digunakan & 4 \\
\hline & e. Memiliki tampilan yang menarik & 5 \\
\hline \multirow{5}{*}{$\begin{array}{l}\text { Kualitas } \\
\text { Informasi }\end{array}$} & a. Menyediakan informasi yang akurat & 1 \\
\hline & $\begin{array}{l}\text { b. Menyediakan informasi yang dapat } \\
\text { dipercaya }\end{array}$ & 2 \\
\hline & $\begin{array}{l}\text { c. Menyediakan informasi yang tepat } \\
\text { waktu }\end{array}$ & 3 \\
\hline & $\begin{array}{l}\text { d. Menyediakan informasi yang mudah } \\
\text { dimengerti }\end{array}$ & 4 \\
\hline & e. Menyediakan informasi yang detail & 5 \\
\hline \multirow{5}{*}{$\begin{array}{l}\text { Kualitas } \\
\text { Interaksi }\end{array}$} & a. Mempunyai reputasi yang baik & 1 \\
\hline & $\begin{array}{l}\text { b. Adanya rasa aman dalam } \\
\text { menyampaikan data pribadi }\end{array}$ & 2 \\
\hline & $\begin{array}{l}\text { c. Menyediakan ruang untuk } \\
\text { personalisasi }\end{array}$ & 3 \\
\hline & $\begin{array}{l}\text { d. Kemudahan dalam memberikan } \\
\text { masukan (feed back) }\end{array}$ & 4 \\
\hline & e. Memberikan pelayanan yang sesuai & 5 \\
\hline \multirow{5}{*}{$\begin{array}{l}\text { Kepuasan } \\
\text { Pengguna }\end{array}$} & a. Kemudahan untuk mengakses & 1 \\
\hline & b. Adanya manfaat penggunaan website & 2 \\
\hline & c. Pelayanan yang sesuai fungsinya & 3 \\
\hline & d. Efisien dan transparan & 4 \\
\hline & $\begin{array}{l}\text { e. Adanya kepuasan pengguna terhadap } \\
\text { kualitas website }\end{array}$ & 5 \\
\hline
\end{tabular}

Subjek penelitian ini adalah pengguna website PPDB yaitu siswa/siswi kelas $\mathrm{X}$ jurusan akomodasi perhotelan pada SMKN 57 Jakarta. Objek yang diteliti adalah kualitas website PPDB terhadap kepuasan pengguna pada SMKN 57 Jakarta.

C. Hasil Penelitian

Untuk menguji apakah alat ukur (instrumen) yang digunakan memenuhi syarat-syarat alat ukur yang baik, sehingga menghasilkan data yang sesuai dengan apa yang diukur, sebelum dilakukan analisis data berdasarkan hasil data yang terkumpul terlebih dahulu dilakukan pengujian data melalui uji validitas dan uji reliabilitas. Setelah uji validitas dan reliabilitas maka dilakukan analisis data dengan melakukan uji asumsi klasik, uji koefisien korelasi dan koefisien determinasi, analisa regresi ganda, uji $t$, dan uji F. Penelitian ini mengambil sampel sebanyak 95 responden dari jumlah populasi 125 responden di SMKN 57 Jakarta. Penelitian ini 
dilakukan dengan teknik kuesioner menggunakan skala likert dan untuk memudahkan perhitungan menggunakan software SPSS 16.

\section{1) Hasil Uji Validitas}

Uji validitas data dilakukan untuk mengukur apakah data yang diberikan pada kuesioner dapat dipercaya atau tidak serta dapat mewakili apa yang hendak diteliti.

Tabel 2.

Hasil Uji Validitas Semua Variabel

\begin{tabular}{|c|c|c|c|}
\hline Variabel & $\begin{array}{l}\text { Nomor } \\
\text { Pertanyaan }\end{array}$ & r-Hitung & Keterangan \\
\hline \multirow{5}{*}{$\begin{array}{l}\text { Variabel } \\
\text { Kualitas } \\
\text { Kegunaan } \\
\left(\mathrm{X}_{1}\right)\end{array}$} & 1 & $.729 * *$ & Valid \\
\hline & 2 & $.769^{* *}$ & Valid \\
\hline & 3 & $.742^{* *}$ & Valid \\
\hline & 4 & $.728^{* *}$ & Valid \\
\hline & 5 & $.709^{* *}$ & Valid \\
\hline \multirow{5}{*}{$\begin{array}{l}\text { Variabel } \\
\text { Kualitas } \\
\text { Informasi } \\
\left(\mathrm{X}_{2}\right)\end{array}$} & 1 & $.732^{* * *}$ & Valid \\
\hline & 2 & $.729^{* * *}$ & Valid \\
\hline & 3 & $.845^{* *}$ & Valid \\
\hline & 4 & $.811^{* * *}$ & Valid \\
\hline & 5 & $.682^{* * *}$ & Valid \\
\hline \multirow{5}{*}{$\begin{array}{l}\text { Variabel } \\
\text { Kualitas } \\
\text { Interaksi } \\
\left(\mathrm{X}_{3}\right)\end{array}$} & 1 & $.792^{* *}$ & Valid \\
\hline & 2 & $.767^{* * *}$ & Valid \\
\hline & 3 & $.814^{* *}$ & Valid \\
\hline & 4 & $.819^{\text {*** }}$ & Valid \\
\hline & 5 & $.672^{* *}$ & Valid \\
\hline \multirow{5}{*}{$\begin{array}{l}\text { Variabel } \\
\text { Kepuasan } \\
\text { Pengguna } \\
\text { (Y) }\end{array}$} & 1 & $.701^{\text {*** }}$ & Valid \\
\hline & 2 & $.701^{* * *}$ & Valid \\
\hline & 3 & $.712^{* * *}$ & Valid \\
\hline & 4 & $.745^{* * *}$ & Valid \\
\hline & 5 & $.826^{* *}$ & Valid \\
\hline
\end{tabular}

Pada tabel di atas, seluruh nilai korelasi atau $r$ hitung setiap pertanyaan lebih dari nilai $\mathrm{r}$ tabel $(0,2039)$. Hal ini berarti hasil pengujian validitas menunjukkan semua item angket dinyatakan valid dan bisa dijadikan sebagai alat pengumpulan data dalam penelitian yang dilakukan.

\section{2) Hasil Uji Reliabilitas}

Uji reliabilitas dimaksudkan untuk mengukur sampai sejauh mana derajat ketepatan, ketelitian atau keakuratan yang ditunjukkan oleh instrumen pengukuran. Uji reliabilitas dilakukan dengan metode internal consistency. Internal consistency diukur dengan menggunakan koefisien Cronbach
Alpha. Ketentuan pengambilan keputusan yang digunakan adalah:

- Jika nilai Alpha > 0,60 maka variabel tersebut berstatus reliabel.

- Jika nilai Alpha < 0,60 maka variabel tersebut berstatus tidak reliabel.

Tabel 3.

Hasil Uji Reliabilitas Semua Variabel

\begin{tabular}{|l|c|c|c|}
\hline Variabel & $\begin{array}{l}\text { Nilai } \\
\text { Cronbach's } \\
\text { Alpha }\end{array}$ & Kriteria & Keterangan \\
\hline $\begin{array}{l}\text { Kualitas } \\
\text { Kegunaan }\end{array}$ & 0.787 & 0.60 & Reliable \\
\hline $\begin{array}{l}\text { Kualitas } \\
\text { Informasi }\end{array}$ & 0.794 & 0.60 & Reliable \\
\hline $\begin{array}{l}\text { Kualitas } \\
\text { Interaksi }\end{array}$ & 0.800 & 0.60 & Reliable \\
\hline $\begin{array}{l}\text { Kepuasan } \\
\text { Pengguna }\end{array}$ & 0.789 & 0.60 & Reliable \\
\hline
\end{tabular}

Berdasarkan hasil uji reliabilitas untuk variabel skor data penelitian dengan menggunakan 95 orang responden, diperoleh nilai reliablitity statistic (cronbach alpha) masing-masing variabel di atas 0,60. Dengan demikian maka data hasil penelitian yang dilakukan adalah reliabel dan memenuhi syarat kualitas data yang baik.

\section{3) Uji Asumsi Klasik}

Sebelum dilakukan analisis dengan regresi linier berganda, dilakukan uji persyaratan analisis terlebih dahulu yang disebut uji asumsi klasik. Uji asumsi klasik meliputi uji normalitas, uji multikolinieritas, uji heterokedastisitas dan uji linieritas.

a) Uji Normalitas

Tabel 4.

Hasil Uji Normalitas

\section{One-Sample Kolmogorov-Smirnov Test}

\begin{tabular}{|ll|l|}
\hline & & $\begin{array}{l}\text { Unstandardize } \\
\text { d Residual }\end{array}$ \\
\hline $\mathrm{N}$ & 95 \\
Normal & Mean & .0000000 \\
Parameters & $\quad$ Std. Deviation & 1.60129156 \\
Most Extreme & Absolute & .080 \\
Differences $\quad$ Positive & .080 \\
& $\quad$ Negative & -.053 \\
Kolmogorov-Smirnov Z & .780 \\
Asymp. Sig. (2-tailed) & .577 \\
\hline
\end{tabular}

a. Test distribution is Normal. 
a. Test distribution is Normal.

Berdasarkan tabel diatas menunjukan bahwa nilai signifikansi $0.577>0.05$ dengan demikian menunjukan bahwa data variabel dalam penelitian ini berdistribusi normal.

b) Uji Multikolinieritas

Pengujian multikolinearitas bertujuan menguji ada tidaknya korelasi yang signifikan yang mendekati sempurna antar variabel independen.

Tabel 5.

Hasil Uji Multikolinieritas

\begin{tabular}{|c|c|c|c|c|c|c|c|c|}
\hline & & \multicolumn{2}{|c|}{$\begin{array}{c}\text { Unstandardized } \\
\text { Coefficients }\end{array}$} & \multirow{2}{*}{\begin{tabular}{|c} 
Standardized \\
Coefficients
\end{tabular}} & \multirow[b]{2}{*}{$t$} & \multirow[b]{2}{*}{ Sig. } & \multicolumn{2}{|c|}{$\begin{array}{c}\text { Collinearity } \\
\text { Statistics }\end{array}$} \\
\hline \multicolumn{2}{|c|}{ Model } & B & Std. Error & & & & Tolerance & VIF \\
\hline 1 & (Constant) & 2.750 & 1.393 & & 1.974 & .051 & & \\
\hline & $\mathrm{X} 1$ & .200 & .108 & .200 & 1.863 & .066 & .339 & 2.947 \\
\hline & $\mathrm{X} 2$ & .296 & .093 & .309 & 3.189 & .002 & .415 & 2.407 \\
\hline & $\mathrm{X} 3$ & .378 & .088 & .390 & 4.283 & .000 & .472 & 2.121 \\
\hline
\end{tabular}

Berdasarkan tabel di atas, maka dapat diketahui nilai VIF kualitas kegunaan $\left(\mathrm{X}_{1}\right)$ adalah 2.947 dan nilai Tolerance adalah 0.339. Nilai VIF kualitas informasi $\left(\mathrm{X}_{2}\right)$ adalah 2.407 dan dan nilai Tolerance adalah 0.415. Nilai VIF kualitas interaksi $\left(\mathrm{X}_{3}\right)$ adalah 2.121 dan nilai Tolerance adalah 0.472 . Nilai Tolerance seluruhnya lebih besar dari 0.01 dan Nilai VIF seluruhnya kurang dari 10, yang berarti tidak terjadi atau bebas dari gejala multikolinieritas.

c) Uji Heterokedastisitas

Tabel 6.

Hasil Uji Heterokedastisitas

Scatterplot

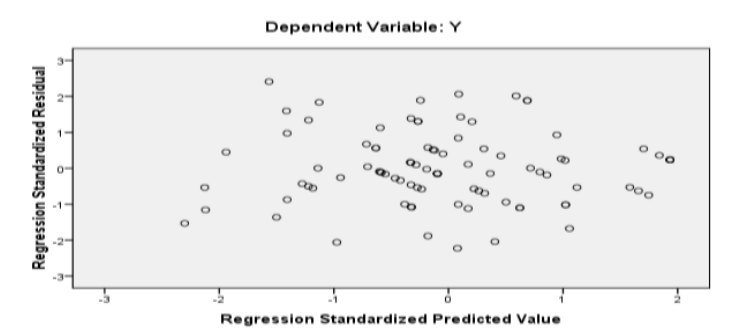

Berdasarkan gambar Scatterplot antara Standardized Residual dan Standardized Predicted Value tidak membentuk suatu pola tertentu, sehingga dapat dianggap residual memiliki varians yang konstan atau tidak terjadi heterokedastisitas. d) Uji Linieritas

Uji linieritas digunakan untuk mengetahui apakah dua variabel mempunyai hubungan yang linier secara signifikan atau tidak.

Tabel 7.

Hasil Uji Linieritas antara Variabel Kualitas Kegunaan dengan Variabel Kepuasan Pengguna

\begin{tabular}{|r|r|r|r|r|r|}
\hline & ANOVA Table & & \\
\hline & Sum of Squares & df & Mean Square & \multicolumn{1}{c|}{$\mathrm{F}$} & \multicolumn{1}{c|}{ Sig. } \\
\hline$Y^{*}$ X1 Between Groups (Combined) & 401.609 & 11 & 36.510 & 10.982 & .000 \\
Linearity & 342.296 & 1 & 342.296 & 102.964 & .000 \\
$\begin{array}{l}\text { Deviation } \\
\text { from }\end{array}$ & & & & & \\
Linearity & 59.313 & 10 & 5.931 & 1.784 & .076 \\
& & & & & \\
Within Groups & 275.928 & 83 & 3.324 & & \\
Total & 677.537 & 94 & & & \\
\hline
\end{tabular}

Berdasarkan tabel 7 di atas, terdapat hubungan yang linear antara variabel kualitas kegunaan $\left(\mathrm{X}_{1}\right)$ dengan variabel kepuasan pengguna (Y).

Tabel 8

Hasil Uji Linieritas antara Variabel Kualitas Informasi dengan Variabel Kepuasan Pengguna

\begin{tabular}{|c|c|c|c|c|c|c|c|}
\hline & & & Sum of Squares & df & Mean Square & $\mathrm{F}$ & Sig. \\
\hline \multirow[t]{7}{*}{$Y * X 2$} & Between Group & (Combined) & 363.735 & 10 & 36.373 & 9.737 & .000 \\
\hline & & Linearity & 337.558 & 1 & 337.558 & 90.359 & .000 \\
\hline & & Deviation & & & & & \\
\hline & & from & 26.177 & 9 & 2.909 & .779 & .637 \\
\hline & & Linearity & & & & & \\
\hline & Vithin Groups & & 313.802 & 84 & 3.736 & & \\
\hline & Total & & 677.537 & 94 & & & \\
\hline
\end{tabular}

Berdasarkan tabel 8 di atas, terdapat hubungan yang linear antara variabel kualitas informasi $\left(\mathrm{X}_{2}\right)$ dengan variabel kepuasan pengguna (Y).

Tabel 9.

Hasil Uji Linieritas antara Variabel Kualitas Interaksi dengan Variabel Kepuasan Pengguna

\begin{tabular}{|c|c|c|c|c|c|c|c|}
\hline \multicolumn{8}{|c|}{ ANOVA Table } \\
\hline & & & Sum of Squares & df & Mean Square & $\mathrm{F}$ & Sig. \\
\hline \multirow[t]{6}{*}{$Y * X 3$} & Between & (Combined) & 384.768 & 11 & 34.979 & 9.917 & .000 \\
\hline & Groups & Linearity & 358.702 & 1 & 358.702 & 101.692 & .000 \\
\hline & & Deviation from & 2606 & . & 2607 & 730 & 600 \\
\hline & & Linearity & 20.000 & 10 & 2.007 & .739 & .080 \\
\hline & Within Gro & & 292.769 & 83 & 3.527 & & \\
\hline & Total & & 677.537 & 94 & & & \\
\hline
\end{tabular}

Berdasarkan tabel 9 di atas, terdapat hubungan yang linear antara variabel kualitas interaksi $\left(\mathrm{X}_{3}\right)$ dengan variabel kepuasan pengguna (Y). 
e) Koefisien Kolerasi dan Koefisien Determinasi

Uji Koefisien Korelasi digunakan untuk mengetahui tingkat keeratan hubungan yang dimiliki antar variabel dalam penelitian.

Tabel 10.

Hasil Uji Koefisien Kolerasi dan Koefisien

Determinasi

\begin{tabular}{|c|c|c|c|c|c|}
\hline \multicolumn{6}{|c|}{ Model Summary ${ }^{\circ}$} \\
\hline Model & $\mathrm{R}$ & R Square & $\begin{array}{l}\text { Adjusted R } \\
\text { Square }\end{array}$ & $\begin{array}{c}\text { Std. Error of the } \\
\text { Estimate }\end{array}$ & Durbin-Watson \\
\hline 1 & $.803^{\mathrm{a}}$ & .644 & .633 & 1.627 & 1.792 \\
\hline
\end{tabular}

a. Predictors: (Constant), X3, X2, X1

b. Dependent Variable: $Y$

Bersadarkan hasil uji koefisien korelasi pada tabel 10, diketahui nilai correlation coefficient sebesar 0.803 maka nilai tersebut menandakan hubungan yang sangat kuat antara kepuasan pengguna dengan kualitas kegunaan, kualitas informasi, dan kualitas interaksi.

Sedangkan koefisien determinasi menunjukkan nilai $=0,644$. Artinya variabel kualitas kegunaan $\left(\mathrm{X}_{1}\right)$, kualitas informasi $\left(\mathrm{X}_{2}\right)$ dan kualitas interaksi $\left(\mathrm{X}_{3}\right)$ dapat menerangkan atau menjelaskan kepuasan pengguna (Y) sebesar 64,4\%, (0.644 X 100\%) sisanya sebesar 35,6 \% dipengaruhi oleh variabel lain yang tidak termasuk dalam model atau persamaan pada penelitian ini.

\section{f) Analisa Regresi Linier Berganda}

Analisa regresi linier berganda digunakan untuk memprediksi atau menguji pengaruh dua atau lebih variabel bebas atau independen terhadap variabel terikat atau dependen.

Tabel 11.

Hasil Analisa Regresi Linier Berganda

\begin{tabular}{|c|c|c|c|c|c|c|c|c|}
\hline & & \multicolumn{2}{|c|}{$\begin{array}{l}\text { Unstandardized } \\
\text { Coefficients }\end{array}$} & \multirow{2}{*}{$\begin{array}{c}\text { Standardized } \\
\text { Coefficients }\end{array}$} & \multirow[b]{2}{*}{$\mathrm{t}$} & \multirow[b]{2}{*}{ Sig. } & \multicolumn{2}{|c|}{ Collinearity Statistics } \\
\hline \multicolumn{2}{|c|}{ Model } & $B$ & Std. Error & & & & Tolerance & VIF \\
\hline 1 & (Constant) & 2.750 & 1.393 & & 1.974 & .051 & & \\
\hline & $\mathrm{x}_{1}$ & .200 & .108 & .200 & 1.863 & .066 & .339 & 2.947 \\
\hline & $\mathrm{x} 2$ & .296 & .093 & .309 & 3.189 & .002 & .415 & 2.407 \\
\hline & $\mathrm{x} 3$ & .378 & .088 & .390 & 4.283 & .000 & .472 & 2.121 \\
\hline
\end{tabular}

Output Keempat (Coeffients) :

Pada tabel coeffient diperoleh persamaan regresi linier berganda dapat ditulis :

$Y=2.750+0,200 X_{1}+0,296 X_{2}+0.378 X_{3}$
$\mathrm{X}_{2}=$ Kualitas Informasi

$\mathrm{X}_{3}=$ Kualitas Interaksi

g) Hasil Uji t

Tabel 12.

Hasil Uji t

Coefficients $^{\mathrm{a}}$

\begin{tabular}{|c|c|c|c|c|c|c|c|c|}
\hline & & \multicolumn{2}{|c|}{$\begin{array}{l}\text { Unstandardized } \\
\text { Coefficients }\end{array}$} & \multirow{2}{*}{\begin{tabular}{|c|}
$\begin{array}{c}\text { Standardized } \\
\text { Coefficients }\end{array}$ \\
Beta \\
\end{tabular}} & \multirow[b]{2}{*}{$\mathrm{t}$} & \multirow[b]{2}{*}{ Sig. } & \multicolumn{2}{|c|}{ Collinearity Statistics } \\
\hline \multicolumn{2}{|c|}{ Model } & $\mathrm{B}$ & Std. Error & & & & Tolerance & $\mathrm{VIF}$ \\
\hline 1 & (Constant) & 2.750 & 1.393 & & 1.974 & .051 & & \\
\hline & $\mathrm{X} 1$ & .200 & .108 & .200 & 1.863 & .066 & .339 & 2.947 \\
\hline & $\mathrm{x} 2$ & .296 & .093 & .309 & 3.189 & .002 & .415 & 2.407 \\
\hline & $\mathrm{X} 3$ & .378 & .088 & .390 & 4.283 & .000 & .472 & 2.121 \\
\hline
\end{tabular}

Berdasarkan Tabel 12 diatas menunjukkan variabel kualitas kegunaan $\left(\mathrm{X}_{1}\right)$ mempunyai nilai $\mathrm{t}$ hitung sebesar 1.863. Nilai t tabel yang merupakan standar untuk mengambil keputusan pada hipotesis dicari dengan menentukan df. Nilai $\mathrm{df}=\mathrm{n}-\mathrm{k}, \mathrm{n}$ adalah jumlah responden dan $\mathrm{k}$ adalah jumlah semua variabel dalam penelitian ini $(\mathrm{df}=\mathrm{n}-\mathrm{k}=95-4=91)$, diperoleh nilai t tabel pada tingkat signifikansi 0,05 yaitu sebesar 1.986. Hasil analisis menunjukkan nilai $\mathrm{t}$ hitung $<\mathrm{t}$ tabel $(1,863<1.986)$. Hal ini berarti Ho diterima dan $\mathrm{H}_{1}$ ditolak, atau tidak terdapat pengaruh (secara parsial) antara kualitas kegunaan terhadap kepuasan pengguna.

Variabel kualitas informasi mempunyai nilai $\mathrm{t}$ sebesar 3.189. Nilai $\mathrm{df}=\mathrm{n}-\mathrm{k}, \mathrm{n}$ adalah jumlah responden dan $\mathrm{k}$ adalah jumlah semua variabel dalam penelitian ini $(\mathrm{df}=\mathrm{n}-\mathrm{k}=95-4=91)$, diperoleh nilai t tabel pada tingkat signifikansi 0,05 yaitu sebesar 1.986. Dari hasil analisis data menunjukkan $\mathrm{t}$ hitung > t tabel, yaitu 3,189>1,986 pada taraf signifikansi sebesar 0,05. Hal ini berarti Ho ditolak dan $\mathrm{H}_{2}$ diterima. Artinya, bahwa terdapat pengaruh (secara parsial) antara variabel kualitas informasi terhadap kepuasan pengguna.

Variabel kualitas interaksi mempunyai nilai $\mathrm{t}$ sebesar 4,283. Nilai $\mathrm{df}=\mathrm{n}-\mathrm{k}, \mathrm{n}$ adalah jumlah responden dan $\mathrm{k}$ adalah jumlah semua variabel dalam penelitian ini $(\mathrm{df}=\mathrm{n}-\mathrm{k}=95-4=91)$, diperoleh nilai t tabel pada tingkat signifikansi 0,05 yaitu sebesar 1.986. Dari hasil analisis data menunjukkan $t$ hitung > t tabel, yaitu 4,283>1.986 pada taraf signifikansi sebesar 0,05. Hal ini berarti Ho ditolak dan $\mathrm{H}_{3}$ diterima. Artinya, bahwa terdapat pengaruh (secara parsial) antara variabel kualitas interaksi terhadap kepuasan pengguna.

Keterangan:

$\mathrm{Y}=$ Kepuasan Pengguna

$\mathrm{X}_{1}=$ Kualitas Kegunaan 
h) Hasil Uji F

Tabel 16.

Hasil Uji F

ANOVA $^{\circ}$

\begin{tabular}{|ll|r|r|r|c|c|}
\hline \multicolumn{1}{|c|}{ ANOVA $^{\text {D }}$} \\
\hline 1 & Regression & 436.508 & 3 & 145.503 & 54.934 & $.000^{\circ}$ \\
& Residual & 241.029 & 91 & 2.649 & & \\
Total & 677.537 & 94 & & & \\
\hline
\end{tabular}

a. Predictors: (Constant), X3, X2, X1

b. Dependent Variable: $Y$

Berdasarkan hasil perhitungan $\mathrm{F}$ hitung diperoleh nilai $F$ sebesar 54.934 dengan signifikansi sebesar 0,000 lebih kecil dari 0,05 . Nilai $F$ tabel diperoleh dengan mencari $\mathrm{N}_{1}$ dan $\mathrm{N}_{2}$, dengan nilai $\mathrm{n}$ adalah jumlah responden (95), $\mathrm{k}$ adalah jumlah semua variabel (4). Dari nilai tersebut, diperoleh nilai $\mathrm{N}_{1}=4-1=3\left(\mathrm{df}=\mathrm{N}_{1}=\mathrm{k}-1\right)$ dan $\mathrm{N}_{2}=95-4=91 \quad\left(\mathrm{df}=\mathrm{N}_{2}=\mathrm{n}-\right.$ k) adalah 2,70. Hasil analisis menunjukkan nilai $F$ hitung > F tabel $(54,934>2,70)$. Hal ini berarti kualitas kegunaan, kualitas informasi, dan kualitas interaksi secara bersama-sama (secara simultan) berpengaruh terhadap kepuasan pengguna.

\section{KESIMPULAN}

1. Hasil pengujian hipotesis diperoleh koefisien determinasi menunjukkan nilai $=0,644$. Artinya variabel kualitas kegunaan $\left(\mathrm{X}_{1}\right)$, kualitas informasi $\left(\mathrm{X}_{2}\right)$ dan kualitas interaksi $\left(\mathrm{X}_{3}\right)$ dapat mempengaruhi kepuasan pengguna $(\mathrm{Y})$ sebesar $64,4 \%,(0.644 \times 100 \%)$ sisanya sebesar $35,6 \%$ dipengaruhi oleh variabel lain yang tidak termasuk dalam penelitian ini.

2. Hasil pengujian hipotesis diperoleh nilai t hitung $<\mathrm{t}$ tabel $(1,863<1.986)$ dengan taraf signifikan sebesar 5\%. Hal ini berarti $\mathrm{H}_{0}$ diterima dan $\mathrm{H}_{1}$ ditolak, atau tidak terdapat pengaruh (secara parsial) antara variabel kualitas kegunaan terhadap kepuasan pengguna.

3. Hasil pengujian hipotesis diperoleh nilai t hitung $>\mathrm{t}$ tabel $(3,189>1,986)$ dengan taraf signifikan $5 \%$. Hal ini berarti $\mathrm{H}_{0}$ ditolak dan $\mathrm{H}_{2}$ diterima, atau terdapat pengaruh (secara parsial) antara variabel kualitas informasi terhadap kepuasan pengguna.

4. Hasil pengujian hipotesis diperoleh nilai t hitung $>\mathrm{t}$ tabel $(4,283>1.986)$ dengan taraf signifikan 5\%. Hal ini berarti $\mathrm{H}_{0}$ ditolak dan $\mathrm{H}_{3}$ diterima, atau terdapat pengaruh (secara parsial) antara variabel kualitas interaksi terhadap kepuasan pengguna.

\section{REFERENSI}

[1] S. Level, A. In, O. F. Online, P. Smkn, and K. Palembang, "Analisis Tingkat Kepuasan dalam
Penerapan PPDB Online SMKN Kota Palembang," vol. 07, no. 02, pp. 23-35, 2017.

[2] Imam Masyhuri; Febriliyan Samopa, "Pengembangan Manajemen Resiko Teknologi Informasi Pada Sistem Penerimaan Peserta Didik Baru (Ppdb Online) Kemdikbud Menggunakan Framework Nist Sp800-30," Pros. Semin. Nas. Manaj. Teknol. XVIII, no. ISBN: 978-602-97491-7-5, pp. 1-7, 2013.

[3] M. R. Afsah, M. Adri, and A. Hadi, "Hubungan Efektifitas Psb Sma Online Dan Kinerja Website Terhadap Kepuasan User Diwilayah Dinas Pendidikan Kota Padang," $J$. Vokasional Tek. Elektron. Inform., vol. 3, no. $1,2015$.

[4] J. Hutahaean, Konsep Sistem Informasi. Yogyakarta: Deepublish, 2015.

[5] J. S. P. Tyoso, Sistem Informasi Manajemen. Yogyakarta: Deepublish, 2016.

[6] S. Hartini, "Metode Webqual pada Analisis Layanan Website PPBD Online Kabupaten Bekasi," Inf. Syst. Educ. Prof., vol. 1, no. 1, pp. 35-41, 2016.

[7] O. G. Hekhmatyar and D. Supriyadi, "Measurement Satisfaction Information System Quality Service On BSI Using Webqual And CSI," Indones. J. onComputer Inf. Technol., vol. 2, no. 2, pp. 1-6, 2017.

[8] A. P. Astuti and P. K. Sari, "Analisis Kualitas Website LAZADA Indonesia Berdasarkan Metode Webqual 4.0 dan Pengaruhnya Terhadap Kepuasan Pengguna," e-Proceeding Manag., vol. 3, no. 2, pp. 1341-1348, 2016.

[9] Y. Farlina and J. M. Hudin, "Kajian Kepuasan Pengguna Informasi Penerimaan Peserta Didik Baru ( PPDB ) Online," Kaji. Kepuasan Pengguna Inf. Penerimaan Peserta Didik Baru Online, vol. 2, no. 2, pp. 48-54, 2017.

[10] M. Kharisma and S. Anggraeni, "Pengaruh Kualitas Layanan BJB Net Terhadap Kepuasan Nasabah Bank BJB Rasuna Said Menggunakan Metode Webqual 4.0," J. Techno Nusa Mandiri, vol. 15, no. 1, pp. 13-18, 2018. 